\title{
PRO-ECOLOGICAL ASPECTS OF THE FUNCTIONING OF SPORTS AND TOURIST FACILITIES WITH AN EXAMPLE OF STADIUMS
}

\author{
A. Kaczmarska \\ Department of Economics University of Economics in Katowice \\ Katowice, Poland
}

\begin{abstract}
Sports events attract thousands of people to stadiums and often give fans and tourists many positive emotions. Stadiums play a major role during sports events, along with players, fans and tourist destinations. They are facilities which over the last two thousand years have transformed into multifunctional venues where you can do the shopping, have a business meeting or visit a museum. However, their ultimate purpose have not been changed. They still provide fans and numerous visitors, who are on that occasion "event" tourists, with unforgettable emotions during sports events.
\end{abstract}

Key vocabulary: modern stadiums, ecological functioning and usage of stadiums.

There is no doubt that international sports events become a heavy burden for the natural environment. Nevertheless, neither tourists nor fans think about these problems during the championships. It is architects, designers, builders and administrators of modern venues who deal with such issues. There are modern technologies called eco-innovations and environmental technologies which help to reduce a negative impact of stadiums and they continue to develop.

This study presents selected aspects of ecological functioning of stadiums. The newly constructed and modernised stadiums can be looked at increasingly eco-friendly venues where the principles of sustainable development are being implemented with a view to reducing their

This is a current issue on account of UEFA EURO 2012 Championships in Poland and Ukraine. The championships evoke many various emotions, while the newly constructed and modernised venues must comply with the requirements of eco-development. Moreover, mass attendance events held at stadiums carry a huge potential of impact. They both affect the local environment and social relations of the local people.

Various functions or even multifunctionality of stadiums results from the necessity to maintain these sports facilities, as well as an urge to increase profits. The key to success is the reduction of a number of days when a stadium is not used and does not earn its keep to an absolute minimum (2,p.99). Multifunctionality of sports facilities can be understood as offering floor space, not only for the purpose of sports. The offer of sports arenas is frequently complemented by conference rooms and office space, bars, restaurants, shopping centres, hotels and museums. Concerts and various sports events are held here.

Service outlets are necessary elements of the functioning of sports stadiums. They bring profits mainly on the day of a match. However, in order to increase profits on a day without a big sports event at a stadium, some of the space is additionally used for conferences, 
wedding receptions, discotheques, parties, banquets, exhibitions, fair trades or business meetings.

Stadiums are becoming equally popular tourist attractions as old churches, castles or old town squares. To a larger extent, it is the unconventional architecture and modernity of sports facilities, as well as the prestige and the brand of a football club which plays at a given stadium that are a magnet for tourists from different parts of the world. Also, the construction works of a stadium themselves attract a large number of people. Hence, for example, during the whole Doors Open Day at the National Stadium in Warsaw more than 140,000 visitors took their seats in the stands (9). Euro Poznań 2012 Ltd. also took a decision to invite visitors to the building site of the Communal Stadium which was being modernised for the European Championship. Several thousands of people came too see it during summer holidays (17).

Museums of sports are at the majority of stadiums of big football clubs and they intensify their function as a tourist attraction. They contain trophies, old photographs and other sports documents. The largest and most frequently visited museum of sport is located at Camp Nou in Barcelona and it is regularly visited by more than one million people each year ).

Hotels are facilities which are often either part of office area of a stadium or they are built next to the sports stands. This is where football stars, business people and fans stay on the day of a match.

Organising concerts in a football pitch is also a key element in multifunctionality of a stadium. The Beatles were the first band to give a concert at the stadium in 1965. The Shea Stadium in New York gathered more than 55,000 people and made the highest profit at that time. It revealed a huge potential of organising concerts on the premises of sports facilities. Another huge event was Live Earth, a series of charity concerts whose aim was to raise people's awareness of increasing carbon dioxide emissions and an issue of global warming. The concerts were held on $7^{\text {th }}$ July 2007 on seven continents and the majority of them were at modern sports stadiums.

It is not only football matches and concerts that fill stadiums to the last seat. Boxing fights, Red Bull X-Fighters (freestyle motocross), Monster Jam and Race of Champions (car races) belong to those untypical sports competitions held at football pitches.

Veltins Arena in Gelsenkirchem can be o model of multifunctionality, where, apart from football matches, they also held biathlon and speedway competitions, handball, ice hockey and American football.

For all sports events mentioned above to be fully realised without excessive environmental damage it is necessary that sports facilities function in an environmentally friendly manner at every stage of their development - designing, life cycle assessment and cost analysis, the use of eco-innovations and eco-friendly technologies, as well as the use of natural resources, such as water and energy, while the facilities are in operation, and also at the stage of waste generation and transport pollution.

\section{Sustainable design}

Constructing and using buildings has a considerable impact on the surrounding landscape and it often generates irreversible environmental changes. Sustainable design is 
a concept which describes a system of solutions which ensure sustainable development. It refers to a decision-making process from the stage of designing, where many criteria must be taken into consideration, including an impact of buildings (construction, exploitation and demolition work) on people and the environment.

The major principles of sustainable design are as follows:

- respect for the environment - this principle is realised through "taking into consideration a cultural context and the use of local resources and building traditions, implementing the idea of the compact urban form, integration with the landscape, expanding the biologically active area";

- respect for the user - understood as "satisfying the needs of a human being, high quality of architecture and space, broad social participation in the process of designing and exploiting, increasing the integrity with the surrounding area through social space and the provision of various forms of ownership or the use of safe materials";

- reduction, reuse and recycling (3R principle): it covers a range of measures taken to save and reuse the area, buildings and materials, to implement water-saving systems, to use rainwater and easily recyclable materials, to manage sewage and waste in a rational way. It also refers to efficient energy use, which is realised through effective insulation, proper orientation of buildings and rooms, minimising heat losses and the passive use of solar energy;

- use of alternative energy sources - this principle is realised through the use of high tech solutions with a view to gaining solar, wind and geothermal energy.

These principles and ways of their implementation contain a wide range of technical solutions and social activities, which, with no doubt, have and will have an influence on the design and construction of buildings and will certainly shape the urban space. Sustainable design discerns the relationship between buildings and the natural environment. Its aim is to reduce the dependence on fossil fuels and toxic substances and to use resources more effectively.

\section{Life Cycle Assessment and Cost Analysis}

The analysis of the following stages of an investment, the use of materials and energy, or exploitation of a stadium itself should be conducted by means of Life Cycle Assessment and Life-Cycle Cost Analysis. "LCA is a process meant to assess environmental impacts associated with all the stages of a product's life through a growth in the effective exploitation of raw materials and the reduction of environmental burden." Environmental impact can be assessed in relation to the product as well as the function. LCA is carried out "fromcradle-to-grave". The key elements of LCA are as follows:

- identification and quantitative assessment of environmental burden,

- evaluation of potential impact of environmental burden,

- evaluation of options to be used in order to reduce burden.

In order to find the link between the impact of the subject of study, in this case - a sports stadium, and the costs, LCA is complemented with Life Cycle Cost Analysis (LCC). According to one of the definitions " $\mathrm{LCC}$ is the total cost of implementation and ownership of a system during its life cycle. It covers the costs of research ad development, marketing, operations, maintenance and repair works, as well as the costs of liquidation or 
economic use of facilities." There are also environmental and social options of LCC: the former additionally determines e.g. charges for economic exploitation of the environment, while the latter determines external costs, direct costs which should be calculated for a selected functional unit and indirect costs calculated for the environment.

\section{Eco-innovations and environmental technologies at sports stadiums}

The concept of environmental technologies can be interpreted in many ways. European Commission in its announcement on "Environmental technologies for sustainable development" and in the subsequent announcements defines them as technologies which are less harmful for the environment than their alternatives. This definition is based on the content of Chapter 34 of Agenda 21 for environmentally friendly technologies, which states that "environmentally friendly technologies protect the environment, generate less pollution, use fewer resources in a more rational way, allow for products and waste to be reused and waste to be treated in a more rational way than the technologies to which they are an alternative. Environmentally friendly technologies with respect to pollution are wastefree processes and production technologies, or they produce a smaller amount of waste for the sake of protection against pollution. (...) Environmentally friendly technologies are not only separate technologies but also complete systems with know-how, procedures, commodities, products and services, facilities, and also standards of organisation and management".

The concept of ecological innovations according to the definition from the late nineties of the 20th century must be understood as "all activities (...), thanks to which new ideas, ways of behaviour, production processes and products are initiated, used and implemented and which protect the environment or aid an ecological dimension of sustainable development". This concept can be narrowed down to such innovations which are in accordance with the policy of environmental protection, that is rational use of resources and a restricted human impact on the environment. Eco-innovations make a contribution not only within environmental aspects, but also within economic and social ones, according to the principles of sustainable development. "It is commonly believed that eco-innovations lead to the development of new processes and products, which not only provide the consumer and the business sector with a value, but they substantially lessen an environmental impact.

The use of materials

The selection and evaluation of materials used for building a stadium should be based on LCA and LCC, that is on their environmental impact. The most frequent ecological solutions applied at the construction stage is using debris and other remains of old facilities, as well as natural materials, recycled materials and materials which can be reused. Moreover, attention should be paid to an amount of energy used and environmental impacts while these materials are excavated, processed, produced, transported or removed.

Water

Water is a very precious resource, so water saving methods and rational water management should play an important role in designing stadiums. Annual water needs at a stadium depend on many various factors. A number of matches and sports events as well as a number of people participating in them are decisive here. Water is mainly used in sports 
changing rooms (showers, bathrooms and catering), for irrigating grass areas of the main football pitch and training football pitches and for irrigating the green areas.

There are many ways to save and reduce an amount of water used and these are often simple, inexpensive investments. The most frequently applied solution is using rain water.

At modern stadiums water from the roofs, lanes and car parks is transported to storage reservoirs, which are built under the ground, behind the stands. Most often, water stored in this way is used for irrigating the grass area and flushing the toilets, which saves potable water. It is also interesting how surface waters are used. The stadium in Hannover can serve as a good example here. It is located in the vicinity of the Ihme river and lake Leine. Water is used there for irrigating the main grass area and two training pitches.

The car parks are covered with the water-pervious honeycomb-shaped surface, which is a saving-water solution which economises on water discharge systems and watering systems. An amount of water stored underneath is used by plants, which results in a "green" car park.

A water-saving solution can be also found in the stadium's toilets. The so-called dry or odourless urinals have been fitted here. An unpleasant smell is neutralised by means of siphons and a special material they are made of. On the other hand, washbasins are fitted with taps which reduce and automatically stop a flow of water.

Suitable water management at the stadium may also help to save water. Computerised systems control the consumption of water. During events with lower attendance some of the sanitary areas are closed and regular inspections of the facilities together with immediate repairs reduce the costs of repairs and the loss of potable water.

Waste materials

An amount of waste produced by spectators is huge. A suitable strategy for waste management is pivotal in reducing an amount of waste and their impact on the environment. Packaging and other consumer goods distributed at the stadium should be made of recycled materials and meant for recycling.

The litter collected during sports and non-sports events at stadiums can be divided into the following groups: plastics, light packaging, paper, cartons, packages, glass, organic waste, residual waste.

Disposable cups for drinks, mainly beer, is a proven and tested solution from the World Cup in Germany. The cups are durable and can be reused, but they are liable to a deposit charge. Such an idea encourages spectators to return the cups and helps to reduce an amount of litter. Selling sausages at the stadium can be ecological too. During the same World Cup in Germany sausages were sold in buns, with a napkin, but without an additional paper plate, whereas ketchup and mustard were available from special disposers, instead of being served as separate portions.

Information about litter containers and their suitable location play a crucial role in the proper segregation of waste. In order to assure a high quality of recycling such containers should be placed at proper distances and in central places inside and outside the sports facilities. Information symbols must be clear and should encourage individuals to collect litter selectively. Despite all these efforts, the responsibility to segregate litter into proper containers lies with fans and tourists. 


\section{Energy}

Equipping modern sports stadium involves using a large amount of energy. Lighting systems at the football pitch and in rooms, air-conditioning, media rooms and office space, shops, heating the building and football pitches - all of these need electric and heat energy.

The most important aspect of a pro-ecological, sustainable sports stadium is reasonable energy usage. There are three major aims concerning energy at stadiums. Firstly, minimising energy demand, secondly, reducing the amount of energy used, if possible, by using renewable energy sources, thirdly, satisfying the rest of demand for energy with nonrenewable energy sources used in the most effective way.

To reach the first aim, that is to minimise the amount of energy used, it is necessary to have energy-saving facilities, effective careful inspection and an energy management system, as well as educational policy to raise the awareness of users.

One of IOC's (International Olympic Committee) missions and roles expressed in the Olympic Charter is "to encourage and support responsible concern for environmental issues, to promote sustainable development in sport and to require that the Olympic Games are held accordingly". The second aim concerning the reduction of energy usage, including the use of 'green' energy, is simultaneously the aim of the International Olympic Committee, in accordance with its mission to promote ecological attitudes. Energy consumption should be based on a detailed burden profile, with a view to matching one's needs with the renewable sources available locally. The differences between the energy demand on "match days" and "non-match days" become crucial here.

The third aim raises the awareness of the fact that the cost cannot be the only factor which affects a decision to select an energy source for a stadium. Different energy resources have impacts on the environment on different levels. One of the criteria must be the reduction of $\mathrm{CO}_{2}$ emissions and should become a major aim in designing stadiums. It is necessary to aim at reducing $\mathrm{CO}_{2}$ emissions in the whole life cycle of the stadium - from the construction stage, through operations to its eventual demolition.

Using day light should be a priority aspect in constructing sports stadiums. Letting the most day light into the facilities eliminates the usage of artificial lighting. It is not only an economic and ecological benefit - spectators benefit from it too, as they prefer natural lighting. Lobbies and light channels turn out to be helpful in letting in natural light.

Artificial lighting is possibly the most obvious element of the stadium's infrastructure which uses huge amounts of energy. It can be saved e.g. by using more efficient lamps and lighting systems, more rational level of lighting, maintenance or inspection systems. Apart from lighting a football pitch, an equally important factor of an ecological stadium is internal lighting. Systems of photocells and movement sensors are usually applied in rarely used rooms, but they also serve their purpose in the outside space of a stadium. Modern technologies help to minimise an amount of energy needed.

Solar energy, wind, geothermal energy and biomass are renewable energy sources most frequently used at sports stadiums.

Among renewable energy sources, solar energy, due to no emission of hazardous substances, has the least negative impact on the natural environment. In the case of wind farms, that is many wind turbines placed one next to another, the most important thing 
is their location. The decision about making an investment must be necessarily preceded by a detailed examination of wind strength in a given location. Geothermal energy and biomass are less frequently used at a stadium, but geothermal energy sources are not liable to changing weather conditions, which is their big advantage.

Transport

During huge sports events the traffic is by large more intense and much heavier. Therefore, the concept of "green" transport is based primarily on public means of transport (municipal transport, railway), because when compared with cars and planes, they generate considerably less harmful exhaust and noise. Moreover, it is important to encourage individuals to lead a healthy and, at the same time, ecological lifestyle, that is to arrive at the stadium on foot or by bicycle. For example, in Salzburg, the host town of EURO 2008, about 2,000 bicycles were parked by the fan zone.

In order to make public transport more efficient it is especially important to provide connections between the stadium and the city centre, railway station or the airport. It is a particularly effective solution if the frequency and volume of public transport on the lines going to and from the stadium on "match "days are increased. If it is not possible to purchase new trains or busses for the championships, the host city may exchange them with the other cities which are less involved in the organisation of the event. This is a way to avoid purchases which are not financially viable and which would become a financial burden for local transport companies, and a situation when the purchased vehicles turn out to be less necessary after the championships are over.

A special system of signs may be helpful for sports fans, particularly those from abroad, to reach the stadium easily and without much trouble. Such a system ought to be clear to understand and the signs should contain the logo of an event, directions as how to get to the stadium, railway station, as well as transport tips.

In order to make transport between the stadium and any other location more efficient, a special ticket has been introduced for sale. It is a combined match and transport ticket. Quite an innovative solution has been introduced in Poland for EURO 2012. The Polish Pass covers not only all transport tickets, but also accommodation and insurance.

An excessive number of cars is one of the major problems of ecological transport. Therefore, many initiatives have been started in order to encourage individuals to choose municipal transport over their own cars on the way to the stadium. One of them is "Park \&ride". It is a system of mixed transport which involves leaving a car in a car park on the outskirts of the city and taking public transport. Limiting the number of parking spaces in the vicinity of the stadium is another solution. Though, it must be stressed here that it is no longer an encouraging or promoting action, but exercising pressure on car users to act accordingly. Other activities promoting ecological transport are as follows:

- special traffic zones around the stadium at the time of a match (permission required),

- operational busses for VIPs, staff and journalists,

- enlarged parking areas for bicycles (promotion of this means of transport),

- environmentally friendly vehicles with low or zero exhaust emission,

- information for travellers and sports fans,

- actions which promote public transport. 


\section{UEFA EURO 2012 stadiums - Poland and Ukraine}

In April 2007 the President of UEFA, Michel Platini, announced a decision to organise UEFA EURO 2012 in Poland and Ukraine. Undoubtedly, it became a huge opportunity for promotion and faster economic progress for both countries. Taking into consideration the development of sports stadiums all over Poland, from the announcement to the opening match stadiums are said to have "boomed". Apart from the EURO arenas, together with two backup stadiums (Kraków and Chorzów) all over Poland, and not only in the biggest cities, old sports facilities underwent modernisation, but primarily new stadiums were constructed.

During the construction works all ecological norms were taken into consideration and the newest environmentally friendly technologies were implemented. Although, these projects are not as spectacular as the ones in, for example, Germany, Australia or Spain. There is no point looking for sports facilities which use renewable energy sources. Despite this fact, it is worth looking closely at the pro-ecological solutions implemented at the stadiums.

The National Stadium in Warsaw is an opening arena of EURO 2012. The facilities with the capacity of 58,000 sports fans were built in the place of the former $10^{\text {th }}$-Anniversary Stadium. Its almost central location enables and encourages sports fans to use public transport on the way to the stadium. Individuals can use trams, trains and the second metro line which is planned to be built in the future. That is the reason why the number of parking spaces has been reduced to 1,765 . A smaller car park allowed for a plot of 5,5 hectares to be planted with 400 trees and 83,000 bushes.

The stadium in Warsaw is fitted with an installation which collects, stores and then uses rain water for flushing 965 toilets. In the rooms on the top deck of the stadium a forcedair heating system has been installed, which in the case of large volume facilities is less energy-consuming. The management and monitoring system for BAS energy installations, on the other hand, gathers information from 30 control points placed at the stadium and allows a quick reaction to a change in temperature in order to use energy in an optimal way. A special outer cover, the so-called second facade, does not only serve an architectural purpose. It prevents the glass offices and other rooms from the sun heat and reduces an amount of energy consumed by air-conditioning.

From among those pro-ecological applications, the choice of the stadium's location and a possibility to use more ecological public transport seem to be the most environmentally friendly solutions.

An additional application of rain water has been implemented at the Municipal Stadium in Wrocław. It will be used for irrigating nearly half a hectare of the green area around the stadium. "Owing to this solution, the administrator of the stadium in Wrocław will economise not only on water, but also on environmental charges, which concern rain water management. It will result in the savings of 119,000 PLN per year, which proves that proecological solutions are generally beneficial also from a purely economic point of view".

Also the modernised Municipal Stadium in Poznań could not do without a system of rain water management - two parallel storage reservoirs of $1,000 \mathrm{~m}^{3}$ were placed one next to the other. Rain water flows to the underground reservoirs and irrigates the grass area of the main football pitch and the training football pitches. Poznan promotes ecological 
transport too. Only 900 parking spaces are meant to encourage sports fans to take public transport to the stadium.

Polish Pass and Polish Guide electronic systems enabled transport connections between the host cities. These products are complementary and facilitate the sports fans and tourists service during the Championships. It is worth mentioning that during the previous championships in Germany and Austria and Switzerland they did not manage to implement such systems. Polish Pass enables its users who have Internet access or telephones equipped with special software to buy plane, train and municipal transport tickets, to pay for accommodation and reservations at hotels and motels, and to purchase health insurance. All these options are integrated in one document.

Polish Guide is an information service with transport options, details of the stadium, fan zones, tourist attractions, accompanying events, as well as medical care and safety.

Pro-ecological solutions applied in all venues make it possible for the operator of each stadium to apply for the EMAS certificate.

The other four stadiums are located in Ukraine, namely in Donetsk (Donbass Arena), Kharkiv (Metalist Stadium), Lviv (Arena Lviv) and Kiev (NSC Olimpiyskiy).

The most environmentally friendly stadium is the stadium in the capital of Ukraine. At the Olympic Stadium in Kiev the "Green wave" project is being realised. Its aim is active participation within management and environmental protection.

This project is based on four main concepts: energy saving, water consumption monitoring, recycling and environmentally friendly transport. These concepts are aided by Extreme Networks Energy Savings Estimator software which evaluates potential savings resulting from proper energy management in the facilities.

During the construction works at the stadium special warm-keeping fences were used and heating systems with an automatic temperature control were improved, which allows to save heat energy. An initiative to introduce the "Green Transport Plan" is meant to help public transport promotion. It aims to convince sports fans that public transport is an outstanding alternative to cars.

The EURO 2012 stadiums are not just another step in pro-ecological development of the venues, as it was the case with Germany, Austria or Switzerland. Despite the lack of alternative energy sources, they were equipped with quite a lot of technology which allows to reduce a negative impact on the environment. It is common knowledge that the organisation of EURO 2012 in Poland lead to a stadium "boom" and the sports facilities have been considerably improved.

\section{Conclusion}

All championships were always an opportunity for masses of people to migrate (sports fans, tourists, business people, etc.) and, at the same time, an opportunity to create and show modernity. Nowadays, the sports venues built for this purpose, just as any other buildings and facilities are expected to minimise a negative impact on the condition of the natural environment. Minimising a negative environmental impact can be done by the reduction of:

- greenhouse gasses emission,

- $\quad$ waste and litter, 
- potable water usage,

- energy consumption,

- noise emission,

- transport,

- a negative impact on living conditions and historic sights,

- a negative impact on biodiversity.

The above measures are connected with the implementation of principles of sustainable development and become an integral part of promoting a country or a host city.

The introduction of eco-development at stadiums begins with a design stage. Such big facilities have a huge influence on the environment, hence various methods to reduce this negative impact. Eco-innovations and many environmental technologies are projects on different scales, from the most spectacular and efficient photovoltaic systems and other sources of renewable energy, through rain water to reusable cups and integrated tickets.

Sports venues are theatres where sportsmen are actors. One sports event attracts tens of thousands of people, as it was in ancient Greece or Rome. Modern typically sports venues evolved into multifunctional facilities. They are a stimulus for economic development of districts and cities and they also serve the society, gather in one place sports fans and tourists from different cultures and nationalities.

Although the stadiums built and modernised for EURO 2012 are not spectacular examples of pro-ecological solutions worldwide, they have become modern and proecological venues in Middle-East Europe. It may additionally encourage Poland and Ukraine to become tourist destinations after the Championships are over.

Summary

Modern sports facilities, led to a multi-functional objects. They spur economic development and urban neighborhoods, serve the public, gather in one place fans and tourists of different cultures and nationalities.

Enter the concept of sustainable development at the stadium starts right from the design phase, because so many objects have a big impact on the environment. There is a need to reduce the negative impact through the use of eco-innovation and environmental technology, starting with the most effective and efficient systems based on renewable energy sources, through the use of rainwater and integrated tickets ending.

Built and modernized stadiums for Euro 2012, although not a spectacular examples of environmentally friendly solutions in the world have become in Central and Eastern Europe modern and attractive facilities for tourists.

\section{LIST OF REFERENCES}

1. BartniczakB., The place of environmental technologies in the implementation of sustainable development, T. Borys, B. Fiedor, Economy versus environment, University of Economics Press in Wrocław, Wrocław 2010,

2. Geraint J., STADIA: A Design and Development Guide, Architectural Press, Oxford 2007,

3. Kowalski Z., Kulczyńska J., Góralczyk M., Ecological evaluation of the life cycle of production processes (LCA), PWN, Warszawa 2007,

4. Schneider-Skalska G., Sustainable design-approaching the realisation, Technical Magazine, 
Cracow University of Technology Press, 3-A/2007,

5. Światek L., Chartynowicz, J. Will the new stadiums litter? Sports facilities as resources in the urban space, W: „Recycling”, 5/2007,

6. Żurawski J., Sustainable design, Pure Energy, No. 1/2010 (101),

7. Olympic Charter, http://olimpijski.pl/pl/files/Download/Karta_Olimpijska_MKOl-2011_ pol-ver.pdf, (accessed on 06.04.2012).

8. http://www.veltins-arena.de, (accessed on 02.12.2011)

9. http://www.stadionnarodowy.org.pl/aktualnosci/1500, ponad-140-tysiecy-zwiedzajacychpodczas-wielkiego-dnia-otwartego, (accessed on 02.12.2011).

10. http://www.rp.pl/artykul/706094.html, (accessed on 18.04.2012).

11. http://www.maccafan.net/Gallery/SheaStadium/Shea.htm, (accessed on 02.12.2011).

12. http://www.komunalny.home.pl/archiwum/?mod=tekst\&id=10809, (accessed on 05.04.2012).

13. http://www.ekologiairynek.pl/sam/135-stadion-narodowy-murawa-zielona-a-reszta-2, (accessed on 18.04.2012).

14. http://www.barcaserwis.com/index.php?co=dzialy\&id=20, (accessed on 02.12.2011)

15. http://panoramamiast.eu/pl/component/content/article/6-turystyka/25-poznanski-stadiongotowy, (accessed on 18.04.2012).

16. http://nsc-olimpiyskiy.com.ua/en/ecology/, (accessed on 18.04.2012).

17. http://euro2012.newsweek.pl/me-2012---stadion-w-poznaniu-stal-sie-atrakcjaturystyczna,42977,1,1.html, (accessed on 02.12.2011).

18. http://eko-polska.pl/articles/article/1091/Polskie-stadiony-co-maja-wsplnego-z-ekologi. html, (accessed on 18.04.2012).

19. Green GoalTM - Legacy Report, http://www.oeko.de/oekodoc/292/2006-011-en.pdf, (accessed on 18.04.2012).

20. http://warszawa.naszemiasto.pl/artykul/1166753, teren-wokol-stadionu-narodowegojednak-bardziej-zielony,id,t.html, (accessed on 18.04.2012)

Стаття: надійшла до редколегї 28.05.2012

прийнята до друку 06.06.2012 


\title{
ЕКОЛОГІЧНІ АСПЕКТИ ФУНКЦІОНУВАННЯ СПОРТИВНИХ І ТУРИСТИЧНИХ ОБ'ЄКТІВ НА ПРИКЛАДІ СТАДІОНІВ
}

\author{
А. Качмарська \\ Департамент економіки, Університет Економіки в Катовіцах \\ Катовіцее, Польщза
}

Спортивні заходи приваблюють тисячі людей на стадіонах і часто дають уболівальникам і туристам багато позитивних емоцій. Стадіони відіграють важливу роль під час спортивних заходів. Вони відносяться до об'єктів, які протягом останніх двох тисяч років перетворилися на багатофункціональні центри, де можна зробити покупки, провести ділову зустріч або відвідати музей. Тим не менш, їх кінцева мета не змінилася. Вони як і раніше забезпечують вболівальників та численних гостей незабутніми емоціями під час спортивних заходів.

Ключові слова: сучасні стадіони, екологічне функціонування, використання стадіонів.

\section{ЭКОЛОГИЧЕСКИЕ АСПЕКТЫ ФУНКЦИОНИРОВАНИЯ СПОРТИВНЫХ И ТУРИСТИЧЕСКИХ ОБЪЕКТОВ НА ПРИМЕРЕ СТАДИОНОВ}

\author{
А. Качмарская \\ Департамент экономики, Университет Экономики в Катовицах \\ Катовице, Польша
}

Спортивные мероприятия привлекают тысячи людей на стадионах и часто дают болельщикам и туристам много положительных эмоций. Стадионы играют важную роль во время спортивных мероприятий. Они относятся к объектам, которые в течение последних двух тысяч лет превратились в многофункциональные центры, где можно сделать покупки, провести деловую встречу или посетить музей. Тем не менее, их конечная цель не изменилась. Они по-прежнему обеспечивают болельщиков и многочисленных гостей незабываемыми эмоциями во время спортивных мероприятий.

Ключевые слова: современные стадионы, экологическое функционирования, использования стадионов. 